\title{
PERANAN BUYA HAMKA DALAM GERAKAN PEMBAHARUAN MUHAMMADIYAH TAHUN 1925-1966
}

\author{
Oleh \\ Tendy Choerul Kamal dan Agus Mulyana ${ }^{1}$
}

\begin{abstract}
The study examined the role of a prominent figure in Indonesian Islamic reform, namely Buya Hamka in Muhammadiyah from 1925 to 1966. The researchers' interest highlighted this issue because when Muhammadiyah experienced problems, Buya Hamka came with all his efforts so that Muhammadiyah did not experience the setbacks. His role in Muhammadiyah wah significant, that between the two can not be separated from each other even the name Buya Hamka is named after a university in Jakarta. Then his determination in principle is worthy of being an example for us as the nation's successor. The main problem of this study is about how Buya Hamka takes the role in Muhammadiyah in 1925-1966. The method used in this study is the historical method by conducting four research stages, namely heuristics, criticism, interpretation, and historiography, and the data collection techniques using literature studies. Based on the results of the study, various efforts were made by Buya Hamka in developing Muhammadiyah including establishing and teaching at Kulliyatul Muballighin, joining a team that determined the status of Muhammadiyah in Masyumi, becoming a member of the Muhammadiyah Articles of Association, and contributing to the Muhammadiyah Personality the grip of Muhammadiyah members who want to jump into politics.
\end{abstract}

Keywords: Buya Hamka, Muhammadiyah, Islamic Renewal

\section{PENDAHULUAN}

Ada banyak faktor yang mengharuskan umat Islam perlu untuk melakukan perubahan-perubahan, salah satu faktornya berasal dari kalangan umat Islam itu sendiri diantaranya adalah banyak umat Islam yang memiliki sifat jumud atau keadaan berdiam diri tidak melakukan perubahan yang menyebabkan semakin jauhnya umat Islam dari ajaran Islam sebenarnya. Maka banyak pihak yang mulai melakukan usaha-usaha pembaharuan dan memperbaiki kegiatan- kegiatan tersebut untuk menegakkan nilainilai Islam. Awal kemunculan gerakan pembaruan Islam di Indonesia baik dalam bentuk anjuran dan ajakan perorangan telah dimulai sekitar akhir abad ke-19 sebelum berdirinya organisasi, sekolah, maupun terbitnya majalah yang menjadi simbol gerakan pembaruan Islam di Indonesia. Sejalan dengan pernyataan di atas, Shihab (1998, hlm. 128) menjelaskan:

Selama tahun-tahun terakhir abad ke-19, gagasan pembaruan Islam mulai diperkenalkan di Indonesia, baik secara

\footnotetext{
${ }^{1}$ Tendy Choerul Kamal adalah mahasiswa pada Departemen Pendidikan Sejarah FPIPS UPI, Agus Mulyana adalah dosen pembimbing I. Penulis dapat dihubungi di nomor 085720064055 / alamat email :Tendychoerulk@gmail.com.
} 
langsung oleh para jamaah haji yang menyampaikan kepada mereka secara lisan maupun secara tidak langsung melalui berbagai penerbitan dan jurnal yang tersebar di kalangan kaum Muslim santri di Indonesia. Dengan demikian semakin banyak saja kaum Muslim Indonesia yang secara perlahan menyadari apa yang tengah berlangsung di dunia Islam lain, khususnya Mesir.

Seiring berjalannya waktu, pembaharuan Islam di Indonesia semakin berkembang dan salah satu alasannya adalah pengaruh dari para jemaah haji. Para jemaah haji yang pulang dari Timur Tengah (Arab) membawa gagasan pembaharuan Islam yang berdampak terhadap masyarakat di sekitarnya. Lalu untuk menyikapi hal tersebut, pemerintah Belanda melakukan berbagai upaya untuk membendung perkembangan pembaharuan Islam di Indonesia. Salah satu upayanya adalah dengan memberlakukan pembatasan jumlah Jemaah haji, sekitar tahun 1825 peraturan ini mulai dilaksanakan. Kemudian biaya yang harus dikeluarkan oleh calon jemaah haji sangat mahal untuk saat itu, seperti yang dijelaskan oleh Arifin (1987, hlm. 66) berkata bahwa “... orang yang akan naik haji harus membayar kepada pemerintah kolonial sebanyak 100 gulden untuk dapat memperoleh surat izin berangkat”.

Lalu pemerintah Belanda membentuk Konsulat di Jeddah untuk mengawasi para calon haji. Selain itu, Belanda mengirim Snouck Hurgronje untuk mempelajari Islam langsung ke Timur Tengah. Meskipun pemerintah Belanda melakukan berbagai upaya untuk membuat Islam sulit berkembang, pada kenyataannya pembaharuan Islam telah menyebar ke berbagai wilayah di Indonesia. Ada banyak tokoh pembaharu Islam yang berasal dari berbagai wilayah di Indonesia belajar langsung ke Timur Tengah, sebagian besar berasal dari Sumatera dan Jawa diantaranya adalah K.H. Ahmad Dahlan, Ahmad Hassan, dan Abdul Karim Amrullah (Djamal, 2002, hlm. 3). Salah satu dari ketiga tokoh tersebut yakni Ahmad Dahlan (selanjutnya disebut Dahlan) kemudian mendirikan Muhammadiyah.

Muhammadiyah didirikan atas saran para kolega dan murid - muridnya. Lalu langkah pertama yang dilakukan Dahlan adalah mensejahterakan masyarakat yang ada di sekitarnya (Mustofa, 2018, hlm. 175). Dahlan terlahir dari keluarga yang memiliki pengaruh di lingkungan Kesultanan Yogyakarta karena ayahnya merupakan salah satu khatib besar di Masjid Kesultanan Yogyakarta. Meskipun tidak mengenyam pendidikan di sekolah formal yang didirikan oleh pemerintah Hindia Belanda atau biasa disebut sekolah Gubernemen, Dahlan belajar langsung kepada ayahnya tentang pendidikan dasar keagamaan. Hal itu juga yang menyebabkan Dahlan semenjak anakanak, sudah biasa mempelajari kitabkitab klasik karangan para ulama. Maka tidak heran apabila kelak Dahlan menjadi salah satu ulama yang banyak jasa-jasanya dalam dunia Islam di Indonesia.

Pada tahun-tahun awal berdirinya, para pengurus Muhammadiyah mendapat permintaan dari berbagai tempat di Pulau Jawa untukmendirikan cabang-cabangnya. Setelah melalui proses yang cukup panjang, tahun 1920 Muhammadiyah memperluas wilayah kegiatannya meliputi seluruh Pulau Jawa. Lalu tahun-tahun selanjutnya wilayah kegiatan Muhammadiyah diperluas kembali meliputi ke seluruh Indonesia. Perluasan ini dipermudah 
oleh berbagai faktor, salah satunya adalah pribadi Dahlan yang menunjukkan toleransi dan pengertian kepada para pendengarnya sehingga memperoleh sambutan yang memuaskan di berbagai wilayah di Indonesia (Noer, 1982, hlm. 87). Selain Dahlan, ada banyak tokoh yang erat kaitannya dengan Muhammadiyah, salah satunya adalah Buya Hamka.

Peneliti tertarik untuk mengkaji sosok Buya Hamka karena dari sekian banyak tokoh pembaharu Islam di Indonesia. Beliau mungkin satu-satunya yang tidak memiliki ijazah diplomat resmi. Buya Hamka memiliki kemampuan untuk menghasilkan banyak karya tulis meskipun kemampuan menulisnya belajar secara otodidak serta memiliki pengaruh besar terhadap perkembangan Islam di Indonesia. Salah satu karya yang fenomenalnya adalah tafsir alazhar, mampu diselesaikan dalam kurun waktu tahun 1964 hingga 1966, ketika ia dipenjarakan oleh Soekarno tanpa melalui proses pengadilan terlebih dahulu. Selain karya tersebut, Buya Hamka banyak melahirkan karya sastra lainnya seperti 'Tenggelamnya Kapal Van Der Wick' dan 'Di Bawah Lindungan Kaba'h yang diangkat ke layar lebar beberapa tahun yang lalu. Salah satu hal yang menarik dari Buya Hamka adalah berdakwah bukan hanya ketika berada di atas mimbar tapi melalui karya-karyanya Buya Hamka berusaha untuk senantiasa menyebarkan Islam melalui pokok-pokok pikirannya.

Buya Hamka juga berperan dalam mengembangkan Muhammadiyah di Indonesia. Hal itu terlihat ketika Hamka di usia senja tetap dipercaya pengurus pusat Muhammadiyah untuk menjadi anggota penasihat pengurus pusat Muhammadiyah yang berkedudukan di Jakarta. Untuk saat ini berbagai sumber yang membahas mengenai sosok Hamka sudah mulai banyak ditemukan, tetapi dari sumber tersebut banyak yang membahas mengenai biografi Hamka dan karya-karya tulisnya. Sumber yang membahas mengenai peranan Hamka di Muhammadiyah belum banyak yang membahasnya. Maka dari itu peneliti tertarik untuk membahas tentang bagaimana peranan Buya Hamka terhadap perkembangan Muhammadiyah.

\section{METODE PENELITIAN}

Menurut Sjamsudin (2012, hlm. 10) metode merupakan suatu prosedur, teknik, atau cara melakukan penyelidikan yang sistematis suatu disiplin ilmu tertentu untuk mendapatkan objek atau bahan yang akan diteliti, jadi yang dimaksud dengan metode adalah tata cara atau langkahlangkah untuk mendapatkan sesuatu dalam hal ini bahan penelitian. Metode historis adalah rekonstruksi imajinatif tentang gambaran masa lampau peristiwaperistiwa sejarah secara kritis dan analitis berdasarkan bukti-bukti dan data peninggalan masa lampau yang disebut sumber sejarah (Ismaun, 2005, hlm. 34). Hal tersebut diperkuat oleh pernyataan Gottschalk (1986, hlm. 32) yang dimaksud dengan metode historis adalah proses pengujian serta menganalisa secara kritis rekaman serta peninggalan masa lampau.

Dalam melaksanakan penelitian sejarah ada beberapa tahap yang harus dilakukan oleh peneliti sebagaimana yang dipaparkan Gray (dalam Sjamsuddin, 2007, hlm. 89) berikut ini:

1. Memilih topik yang sesuai

2. Mengusut semua bukti yang relevan dengan topik

3. Membuat catatan tentang itu, apa saja yang diangap penting dan relevan 
dengan topik yang ditemukan ketika penelitian sedang berlangsung

4. Mengevaluasi secara kritis semua bukti yang telah disimpulkan atau melakukan kritik terhadap sumber

5. Menyusun hasil-hasil penelitian berupa catatan fakta-fakta ke dalam suatu pola yang benar dan berarti, yaitu sitematika yang telah disiapkan sebelumnya

6. Menyajikan dalam suatu cara yang dapat menarik perhatian dan mengkomunikasikannya kepada para pembaca sehingga dapat dimengerti sejelas mungkin.

Berikut adalah langkah-langkah penelitidalam melaksanakan penelitiannya sebagaimana yang diungkapkan oleh Ismaun (2005, hlm. 34) ada empat tahapan yang harus dilewati oleh sejarawan untuk menuliskan sejarah kembali berdasarkan bukti-bukti yang ada. Empat tahapan tersebut ialah:

1. Heuristik merupakan tahapan awal dalam proses penelitian sejarah yaitu mencari atau mengumpulkan berbagai sumber sejarah yang dianggap sesuai dengan topik yang dipilih sebelumnya. Proses heuristik tidak mengenal suatu peraturan-peraturan umum dan dibutuhkan suatu keterampilan dalam pengumpulan, menangani, dan memerinci bibliografi atau mengklasifikasi berbagai sumber yang ditemukan dan sumber yang digunakan adalah sumber benda, sumber tertulis, dan sumber lisan.

2. Kritik merupakan tahapan selanjutnya dalam proses penelitian sejarah yaitu memilah dan memilih serta menganalisis sumber yang telah ditemukan sebelumnya. Hal ini dilakukan supaya unsur objektifitas dalam penelitian sejarah dapat dipertanggungjawabkan. Pada tahapan ini pada akhirnya akan menentukkan sumber mana yang sesuai dan digunakan. Kritik terbagi menjadi dua yaitu kritik eksternal dan kritik internal.

3. Interpretasi merupakan penafsiran terhadap fakta - fakta yang telah didapatkan pada proses heuristik dan telah melalui kritik eksternal dan internal. Peneliti akan melakukan penafsiran terhadap fakta satu dengan fakta lainnya sehingga akan mendapatkan suatu kesimpulan yang dapat menghubungkan antara fakta satu dengan lainnya.

4. Historiografi merupakan tahapan terakhir dalam penelitian sejarah. Pada tahapan ini peneliti akan menyusun hasil temuan sebelumnya dengan menggunakan gaya bahasa yang baik dan benar dalam bentuk tulisan.

Dalam penelitian ini peneliti menggunakan pendekatan interdisipliner yang dapat meminjam sudut pandang disiplin ilmu lain untuk membantu ilmu sejarah dalam mengkaji permasalahanpermasalahan yang terdapat pada rumusan masalah penelitian. Peneliti pun melakukan rekonstruksi mengenai masa lampau dengan menggunakan studi literatur sebagai teknik penelitiannya.

\section{HASIL PENELITIAN DAN PEMBAHASAN}

Hamka lahir pada tanggal 16 Februari 1908 (versi lain 17 Februari) di Maninjau, Kabupaten Agam, Sumatera Barat. Nama lahir Hamka adalah Abdul Malik, sedangkan nama Hamka sendiri merupakan nama pena yang digunakan 
selama ia aktif menulis ketika berada di Medan. Hamka merupakan anak tertua dari empat bersaudara dari pasangan Abdul Karim Amrullah dan Siti Safiyah. Belakangan Hamka diberi sebutan Buya, yaitu sebutan untuk orang Minangkabau yang berasal dari kata abi atau abuya dalam bahasa Arab, yang berarti ayahku atau seseorang yang dihormati (Kurniawan \& Mahrus, 2011, hlm. 225).

Jika dilihat dari silsilah keturunannya, Hamka merupakan keturunan salah satu pahlawan Perang Paderi yakni Abdul Arif yang bergelar Tuanku Pauh Pariaman atau lebih dikenal sebagai Tuanku Nan Tuo. Kakek Hamka adalah Syekh Muhammad Amrullah yang menikah sebanyak delapan kali dan dikarunia empat puluh enam anak. Salah satu anaknya yakni Abdul Karim Amrullah yang tak lain adalah ayah Hamka, terkenal sebagai tokoh pembaharu Islam bersama kaum mudanya. Nama lahir Abdul Karim Amrullah adalah Muhammad Rasul. Tetapi, setelah pergi ke Mekkah untuk menunaikan ibadah haji, ia kemudian dipanggil dengan nama Haji Abdul Karim Amrullah. Biasanya orang-orang banyak mengenalnya dengan sebutan Haji Rasul serta keluarga terdekatnya memanggil ia dengan sebutan Innyiak Doktor (Aizid, 2017, hlm. 411). Meskipun sang ayah merupakan salah satu tokoh tarekat naqshabandiyah, kelak Haji Rasul lah salah satu orang yang akan menentang keras praktek-praktek tarekat naqshabandiyah yang tidak sesuai dengan ajaran Islam.

Ketika masih anak-anak, Hamka gemar melakukan banyak hal seperti menonton film bisu, mendengarkan tukang cerita atau biasa disebut tukang kaba, dan satu hal yang menarik dari Hamka adalah sejak anak-anak ia sudah mempunyai minat yang tinggi terhadap buku-buku sehingga beberapa kali ia tidak masuk sekolah hanya untuk membaca koleksi buku di Bibliotek. Suatu ketika Haji Rasul mendapati Hamka sedang membaca koleksi buku dari Bibliotek yang sama sekali tidak ada hubungannya dengan buku pelajaran, tentu saja ia marah besar sehingga tidak mengizinkan Hamka untuk keluar rumah sesuka hatinya lagi seperti sebelumnya (Musyafa, 2016, hlm. 48).

Kebiasaan Hamka pun masih berlanjut meskipun dilarang oleh ayahnya untuk datang ke Bibliotek, setiap selesai membaca buku maka Hamka akan membuat salinan versinya sendiri. Hamka merupakan salah satu ulama yang unik, karena tercatat hingga akhir hayatnya pendidikan yang ditempuhnya tidaklah tinggi hanya sebatas kelas dua di Sekolah Desa. Tetapi kecerdasan yang dimilikinya serta rasa ingin tahu yang tinggi membuatnya belajar secara otodidak hingga menjadi sosok yang begitu banyak dikagumi melalui karyakarya yang dihasilkannya.

Pendidikan awal yang diterima Hamka yaitu membaca Al-Quran dan kitab-kitab berbahasa Arab. Selain belajar bersama ayahnya, Hamka juga belajar dengan kakak tirinya yang bernama Fatimah. Bersama kakaknya, Hamka mulai belajar mendirikan shalat lima waktu dengan benar. Kakaknya ini bersifat pemarah, bahkan beberapa kali mencubit Hamka ketika tidak mengerti apa yang diajarkannya. Menginjak usia sekitar tujuh tahun, Hamka mulai belajar di sekolah formal. Awalnya Haji Rasul berniat untuk mendaftarkan Hamka ke Sekolah Gubernemen. Namun hal tersebut tidak terlaksana karena waktu pendaftaran telah selesai. Sehingga Haji Rasul memutuskan untuk mendaftarkan Hamka ke Sekolah 
Rakyat atau Sekolah Desa untuk belajar pengetahuan umum. Meskipun gagal sekolah di Sekolah Gubernemen karena waktu pendaftaran sudah keburu tutup, tapi Malik masih bisa diterima di Sekolah Rakyat (El-Jaquene, 2018, hlm. 45).

Hamka termasuk orang yang suka belajar secara mandiri atau otodidak sehinggamudahmerasabosanketikabelajar di Sekolah Diniyah dan Thawalib. Salah satu kegemaran Hamka adalah membaca, maka kegiatan yang dilakukannya ketika merasa bosan belajar di Sekolah Diniyah dan Thawalib adalah membaca koleksi buku-buku yang terdapat di Bibliotek Zainaro. Bibliotek Zainaro adalah sebuah perpustakaan buku yang didirikan oleh Zainuddin Labay. Di tempat itu, Hamka banyak membaca buku-buku berbahasa Melayu, novel-novel karya Marah Rusli dan Abdul Muis, hingga membaca bukubuku tentang pemikiran Djamaluddin Al-Afgani, Muhammad Abduh, H.O.S Cokroaminoto, K.H. Mas Mansur, Ki Bagus Hadikusumo, H. Fachruddin, dan lain-lain. Sering membaca pemikiran tokoh serta perkembangan Islam di daerah lain seperti di Jawa, membuka cakrawala pemikiran Hamka, hingga ia memiliki keinginan agar suatu saat bisa pergi ke Jawa.

Hamka mulai terjun ke dunia politik sekitar tahun 1925, ketika ia memutuskan untuk bergabung dengan salah satu organisasi terbesar saat itu yakni Sarekat Islam (Faidi, 2014, hlm. 82). Hal tersebut senada dengan apa yang diungkapkan oleh Hamka (2016, hlm. 233) menjelaskan bahwa adik kandung ayahnya atau pamannya yakni Djafar Amrullah lah yang mengajak Hamka untuk bergabung dengan Sarekat Islam. Kegemarannya membaca buku telah membukakan cakrawala pemikirannya. Setelah melewati masa-masa sulit, Hamka mempunyai keinginan untuk pergi ke Jawa setelah mendengar berbagai informasi tentang perkembangan Pulau Jawa dari bukubuku yang dibacanya.

Pada tahun 1924 Hamka pergi Jawa dan langsung menuju ke Yogyakarta. Pada saat itu Hindia Belanda sedang dilanda gelombang agitasi politik (Rush, 2017, hlm. 69). Oleh pamannya, Hamka mendapat kesempatan untuk mengikuti berbagai diskusi dan pelatihan pergerakan Islam melalui organisasi Sarekat Islam dan Muhammadiyah. Hamka mulai berkenalan dengan tokoh - tokoh Islam seperti H.O.S. Cokroaminoto, Haji Fachruddin, RM. Suryopranoto dan Ki Bagus Hadikusumo. Seiring berjalannya waktu, Hamka tertarik untuk menggabungkan diri dengan Sarekat Islam yang ketika itu dipimpin oleh H.O.S. Cokroaminoto. Dibantu oleh pamannya, Hamka berhasil masuk dan menjadi anggota Sarekat Islam.

Selama mengikuti kursus yang diadakan oleh Sarekat Islam, Hamka bersungguh-sungguh mempelajari materimateri kursus. Setelah mengikuti kursus inilah Hamka mengetahui bahwa Islam itu adalah suatu yang hidup serta menemukan suatu organisasi pergerakan di Jawa yang bertujuan untuk memajukan umat Islam, berbeda dengan umat Islam yang berada di Minangkabau karena umumnya mereka masih memperdebatkan praktik ritual Islam. Selain menjadi anggota Sarekat Islam, Hamka pun akhirnya memutuskan untuk bergabung dengan Muhammadiyah setelah belajar kepada Haji Fachruddin. Selama di Yogyakarta, beberapa kali Hamka ikut rombongan perwakilan Sarekat Islam dan Muhammadiyah ke Bandung. Pada saat di Bandung, Hamka berkenalan dengan Mohammad Natsir dan Ahmad Hassan. 
TENDY CHOERUL KAMAL DAN AGUS MULYANA

PERANAN BUYA HAMKA DALAM GERAKAN PEMBAHARUAN MUHAMMADIYAH

TAHUN 1925-1966

Pertengahan tahun 1925, Hamka Tahun 1927 akhirnya Hamka memutuskan kembali ke Padang menunaikan ibadah hajinya untuk Panjang untuk mendirikan Tabligh pertama kalinya. Ketika menjelang Muhammadiyah dan Chatibul Ummah waktu pelaksanaan ibadah haji, Hamka (Alfian, 2014, hlm. 26). Gurunya yaitu Zainuddin Labay membantunya untuk membuat dan mendistribusikan majalah tersebut. Di tahun sama Sutan Mansur mengikuti Hamka ke Padang Panjang untuk menjadi mubaligh dan menyebarkan Muhammadiyah dibantu oleh Hamka. Ketika itu perkumpulan Sendi Aman yang sudah ada sebelumnya, dirubah menjadi cabang Muhammadiyah. Sejak saat itulah Hamka menjadi pengiring Sutan Mansur dalam setiap kegiatan Muhammadiyah. Muhammadiyah di Minangkabau mengalami kemajuan yang cukup pesat hal itu diungkapkan oleh Djamal (2002, hlm. 85) menjelaskan:

Di antara sejumlah persatuan pembaruan, Sarekat Islam dan Muhammadiyah merupakan dua organisasi yang paling penting yang memenuhiperananreformasi,terutama selama tiga dasawarsa pertama abad ke-20. Sejauh menyangkut wilayah Minagkabau, Muhammadiyah sangat berhasil mengumandangkan gagasangagasan Modernisme Islam, walaupun Sarekat Islam datang beberapa tahun lebih awal ke daerah itu.

Hamka mengiringi Sutan Mansur sebagai utusan pengurus besar Muhammadiyah untuk membangun cabang-cabang Muhammadiyah di Pagar Alam, Lakitan, dan Kurai Taji. Lalu pada perkembangan selanjutnya, Hamka diangkat menjadi wakil ketua Muhammadiyah cabang Padang Panjang mendampingi Syekh Jalaluddin Rajo Endah IV. bergabung dengan kelompok Persatuan Hindia-Timur (El-Jaquene, 2018, hlm. 66). Kelompok itu merupakan sebuah organisasi yang memberikan pelajaran manasik haji kepada calon jamaah haji asal Indonesia. Selama berada di Mekkah, Hamka tinggal di rumah seorang pemandu haji yaitu Amin Idris dan untuk bertahan hidup selama berada di Mekkah, Hamka ikut bekerja di percetakan milik Tuan Hamid Kurdi yang tak lain adalah mertua ulama Minangkabau yang sudah terkenal yaitu Syekh Ahmad Khatib.

Setelah menunaikan ibadah haji, Hamka tidak langsung kembali ke tanah air melainkan ingin tinggal beberapa waktu di Mekkah, namun keinginan itu tidak terwujud setelah bertemu Haji Agus Salim yang memberi nasihat untuk pulang ke Indonesia. Kemudian Hamka pulang ke Indonesia namun bukan Padang Panjang tujuannya melainkan Medan. Mulai dari sinilah ia mulai rajin menghasilkan banyak karya dan memperkenalkan nama penanya HAMKA. Setelah dibujuk oleh Sutan Mansur untuk segera kembali ke rumah ayahnya yang berada di Sungai Batang, Hamka pun menyetujuinya (Musyafa, 2016, hlm. 309-312).

Ketika banyak pihak yang menilai tepat waktunya untuk mendirikan sebuah perguruan yang mencetak kader-kader Muhammadiyah yang berkompeten, atas usul Abdullah Kamil tahun 1929 didirikan suatu perguruan yang diberi nama Tabligh School. Untuk guru-gurunya adalah Sutan Mansur, Sutan Mangkuto, Abdullah Kamil, Hamka, dan Muhammad Rasyid Idris. Kemudian pelajaran yang diajarkan 
diantaranya tentang kepemimpinan dan taktik bagaimana caranya berdakwah untuk menarik perhatian masyarakat. Tabligh School menggunakan cara mengajar yang berbeda dengan yang lainnya sehingga menarik cukup banyak peminat saat itu (Isnaeni dalam Historia, 2018, hlm. 59). Waktu pembelajarannya dilaksanakan setiap selasa malam di Gedung Muhammadiyah yang berlokasi di Guguk Malintang. Namun pada tahun 1931, perguruan ini berhenti beroperasi karena satu dan lain hal.

Secara resmi Kulliyatul Muballighin didirikan tahun 1935. Setiap cabang-cabang Muhammadiyah yang ada di Sumatera Barat diberikan maklumat pembukaan dan program mengenai Kulliyatul Muballighin ini. Perguruan yang didirikan oleh Hamka ini memberikan kesempatan kepada para lulusan Sumatera Thawalib, Sekolah Diniyah, dan sekolah-sekolah lainnya untuk bergabung. Kemudian di tahun yang sama Hamka dilantik menjadi Majelis Konsul Muhammadiyah Sumatera Tengah (Ramly \& Sucipto, 2010, hlm. 178). Guru-guru yang mengajar di perguruan ini kurang lebih sama seperti yang pernah mengajar di Tabligh School seperti Hamka, Sutan Mansur, Sutan Mangkuto, dan Abdullah Kamil.

Setelah disetujui dalam konferensi, dimulailah perbaikan-perbaikan mengenai pengajaran di Kulliyatul Muballighin yang dilaksanakan ketika usianya masuk tahun kedua. Salah satu perbaikan yang dilakukan adalah guru yang mengajar di Kulliyatul Muballighin diantaranya Sutan Mansur, Haji Rasul, Hamka, Daud Rasyidi, Sutan Mangkuto, Abdullah Kamil, Yakub Rasyid, Muhammad Rasyid Idris, Adam Ibrahim, Badaruddin Zain, dan lainlain. Kurikulum yang digunakan dalam
Kulliyatul Muballighin bisa dikatakan sudah lengkap antara ilmu agama dan ilmu umum, maka lulusan dari perguruan ini sudah bisa mengimbangi bahkan melebihi para lulusan sekolah-sekolah yang dibentuk oleh pemerintah Belanda.

Ketika Muktamar Muhammadiyah ke-32 yang bertempat di Purwekerto dilaksanakan terdapat beberapa hal yang dibahasa di dalamnya seperti bagaimana sikap Muhammadiyah terhadap pemilihan umum yang akan dilaksanakan tahun 1955 serta membahas tentang susunan pengurus pusat Muhammadiyah periode tahun 1953 hingga tahun 1956. Untuk ketua terpilih dalam muktamar yang diselenggarakan ini adalah A.R. Sutan Mansur yang tak lain adalah kakak ipar Hamka. Kemudian Hamka terpilih juga sebagai anggota pengurus pusat Muhammadiyah.

Hubungan Partai Masyumi dengan Muhammadiyah pada awalnya berjalan dengan baik, namun menjelang pemilihan umum tahun 1955 hubungan diantara keduanya mengalami keretakan. Hal tersebut tentu bukan suatu hal yang baik, karena Muhammadiyah tercatat sebagai anggota istimewa dari Partai Masyumi. Apalagi semenjak keluarnya NU dari Partai Masyumi tahun 1952, posisi Muhammadiyah di dalam Partai Masyumi semakin kuat (Syaifullah, 1997, hlm. 161). Posisi Muhammadiyah sangat berpengaruh karena sebagian besar anggota Muhammadiyah adalah orangorang yang duduk dalam Partai Masyumi.

Setelah adanya beberapa kelompok corak pemikiran yang menimbulkan perdebatan di dalam Muhammadiyah, maka dibentuklah suatu tim yang terdiri dari empat orang yaitu A.R. Sutan Mansur, Abdul Malik Ahmad, Muhammad Yunan Nasution, dan Hamka. Setelah melakukan 
pembicaraan yang memakan waktu tidak terlalu lama maka disepakati beberapa kesepakatan. Dijelaskan Mujahid (2013, hlm. 34) isi kesepakatan tersebut adalah sebagai berikut:

"Muhammadiyah

tetap

Muhammadiyah, berjalan menurut Khittah yang telah ditentukan; sedang yang khusus soal-soal praktis politik disalurkan dan diatur bersama dalam Masyumi. Anggota Muhammadiyah yang berkeinginan berjuang dalam lapangan politik secara langsung, dianjurkan masuk partai politik Islam Masyumi. Hasil perundingan antara Pusat Pimpinan Muhammadiyah dengan Pimpinan Partai Masyumi diterima oleh Majelis Tanwir secara bulat (aklamasi)."

Kemudian setelah terjadi kesepakatan yang diatas maka Pusat Pimpinan Muhammadiyah dan Pimpinan Partai Masyumi memutuskan bahwa status keanggotaan istimewa Muhammadiyah dihapuskan. Adapun cara penghapusan status istimewa Muhammadiyah tidak menimbulkan konflik baru. Sebelum adanya penghapusan itu hubungan Muhammadiyah dengan Partai Masyumi berjalan sebaik-baiknya. Peran Hamka dalam menyelesaikan berbagai persoalan yang terjadi dalam Muhammadiyah bisa dikatakan berhasil. Seandainya persoalan mengenai meruncingnya hubungan Muhammadiyah dengan Partai Masyumi bisa berdampak terhadap keberlanjutan Muhammadiyah di Indonesia khususnya di bidang politik antar umat Islam.

Lalu tahun 1950 Muhammadiyah melaksanakan muktamar yang salah satu bahasannya adalah memilih dan menetapkan Ki Bagus Hadikusumo menjadi Ketua Pengurus Pusat
Muhammadiyah. Ada juga usaha untuk melakukan pendataan ulang untuk status keanggotaan cabang dan ranting Muhammadiyah karena pada saat itu keamanan di setiap daerah di Indonesia belum sepenuhnya pulih. Hal itu berakibat terhadap kedatangan perwakilan dari setiap cabang dan ranting yang tidak dapat hadir saat acara muktamar dilaksanakan. Pada masa periode kepemimpinan Ki Bagus Hadikusumo, ada beberapa keputusan penting yang diambil terhadap keberlangsungan berdirinya Muhammadiyah dan salah satunya adalah merumuskan Muqaddimah Anggaran Dasar Muhammadiyah.

Ki Bagus Hadikusumo merumuskan Muqaddimah Anggaran Dasar Muhammadiyah dikarenakan untuk mengatasi problem dalam diri Muhammadiyah sendiri, karena setelah 40 tahun berdiri Muhammadiyah berkiprah di Indonesia mulai terasa perjuangan dalam menyebarkan dakwah Islam yang dilakukan oleh para anggota Muhammadiyah terasa melemah. Hal itu terjadi karena adanya faktor dari luar yang merubah pemikiran setiap anggota Muhammadiyah serta faktor dari dalam diri setiap anggota Muhammadiyah. Sehingga Muqaddimah Anggaran Dasar Muhammadiyah dirumuskan oleh Ki Bagus Hadikusumo dibantu oleh beberapa anggota Muhammadiyah diantaranya K.H. Farid Ma'ruf, Mr. Kasman Singodimedjo, Hamka, dan Zein Jambek.

Muqaddimah yang disusun pada periode kepemimpinan Ki Bagus Hadikusumo （1943-1953） sebenarnya sudah mulai dirumuskan prinsip-prinsip pemikirannya sejak tahun 1945 namun karena kondisi dan situasi di Indonesia belum stabil maka akhirnya bisa dibawa 
dan disahkan pada tahun 1951. Hal ini dilakukan oleh Ki Bagus Hadikusumo sebagai hasil dari membangun kembali pikiran-pikiran K.H. Ahmad Dahlan ketika mendirikan Muhammadiyah pertama kali. Hamka beserta dengan beberapa temannya mempunyai konsep lain mengenai Muqaddimah Anggaran Dasar Muhammadiyah yang isinya lebih menitikberatkan pada peranan dan sumbangsih Muhammadiyah dalam mengisi kemerdekaan dan pembangunan bangsa Indonesia.

Adanya dua konsep yang diusung membuat Muktamar belum memutuskan konsep mana yang akan dipilih, sehingga ketika sidang Tanwir tahun 1951 menerima konsep yang diusulkan oleh Ki Bagus Hadikusumo. Lalu untuk penyempurnaan susunan redaksionalnya, dibentuklah sebuah tim yang terdiri dari Hamka, Kasman Singodimedjo, Farid Ma'ruf, dan Zein Djambek. Maka setelah disusunnya Muqaddimah Anggaran Dasar Muhammadiyah ini memiliki tujuan agar setiap anggota Muhammadiyah untuk senantiasa memiliki jiwa dan semangat untuk mengabdikan diri dan memperjuangkan Muhammadiyah kepada masyarakat sesuai dengan tujuan awal didirikannya Muhammadiyah pertama kali oleh Ahmad Dahlan.

Kepribadian Muhammadiyah merupakan salah satu dari beberapa rumusan resmi persyarikatan yang disahkan oleh Muktamar Muhammadiyah ke -35 tahun 1962 di Jakarta. Muktamar Muhammadiyah yang dimaksud untuk sekarang lebih dikenal sebagai Muktamar setengah abad. Perumusan kepribadian Muhammadiyah ketika itu tidak bisa dilepaskan oleh situasi politik yang saat itu berlangsung. Jika kita melihat tahun diadakannya Muktamar Muhammadiyah itu berada ketika sistem pemerintahan demokrasi terpimpin. Demokrasi terpimpin yang dikumandangkan oleh Soekarno mulai berlaku dari tanggal 5 Juli tahun 1959 (Hanggoro dalam Historia, 2018, hlm. 82).

Setelah dibubarkannya Partai Masyumi, para anggota Muhammadiyah yang asalnya berjuang dalam medan politik praktis kembali mengaktifkan diri dalam Muhammadiyah. Namun akibatnya, para anggota Muhammadiyah yang aktif di perpolitikan membawa kebiasaan mereka yang terbiasa menjalani politik praktis ketika masih menjadi anggota Partai Masyumi. Hal tersebut dikhawatirkan akan merusak Muhammadiyah yang selama ini tidak menjalani politik praktis (Miswanto, 2012, hlm. 68). Hamka adalah salah satu anggota Muhammadiyah yang ikut terdaftar sebagai anggota Konstituante mewakili Partai Masyumi. Lalu Hamka kembali mengaktifkan diri kembali dalam Muhammadiyah akan tetapi tidak melanjutkan perjuangan politik praktis dan lebih fokus kepada bidang dakwah.

Kepribadian Muhammadiyah adalah rumusan yang menggambarkan tentang hakekat Muhammadiyah, serta apa yang menjadi pedoman amal usaha dan perjuangan Muhammadiyah, serta sifat sifat yang dimilikinya (Nashir dalam Miswanto, 2012, hlm. 67). Semua itu dimulai ketika pertentangan antar ideologi dengan partainya masingmasing, Muhammadiyah mengadakan sebuah kursus yang dilaksanakan di Kota Yogyakarta. Di antara beberapa yang mengisi acara untuk ceramah terdapat salah satu nama yang menarik perhatian para peserta kursus, ia adalah K.H. Fakih Usman. K.H. Fakih Usman tercatat 
pernah menduduki posisi penting di Muhammadiyah maupun Partai Masyumi.

Ketika mendapat kesempatan untuk mengisi acara kursus, K.H. Fakih Usman menyampaikan makalahnya yang berjudul “Apakah Muhammadiyah itu?”. Dalam penyampaiannya, K.H. Fakih Usman menjelaskan berbagai hal yang berkaitan dengan Muhammadiyah seperti jati diri Muhammadiyah dan menjelaskan apa dan siapa Muhammadiyah. Apa yang disampaikan oleh K.H. Fakih Usman ternyata mendapat perhatian dari beberapa tokoh Muhammadiyah, karena saat itu para anggota Muhammadiyah membutuhkan identitas sebagai pegangan karena situasi dan kondisi yang serba tidak menentukan. Untuk itu dibentuklah sebuah tim yang ditugaskan untuk merumuskan tentang Kepribadian Muhammadiyah yang terdiri dari K.H. Wardan Diponingrat, Hamka, H. Djarnawi Hadikusuma, H.M. Djindar Tamimy, H.M. Saleh Ibrahim, dan K.H. Fakih Usman sebagai narasumber (Pasha dan Darban, 200o, hlm. 180).

Tim yang dibentuk kemudian merumuskan apa yang nanti dinamakan sebagai Kepribadian Muhammadiyah, selanjutnya hasil dari rumusan ini dibawa ke dalam Sidang Tanwir tanggal 25 sampai 28 Agustus tahun 1962 yang dilaksanakan di Jakarta. Kemudian hasil Sidang Tanwir ini dibawa ke dalam Muktamar ke-35 Muhammadiyah atau Muktamar Setengah Abad tahun 1962 yang berlangsung juga di Jakarta. Dalam penyusunan kepribadian Muhammadiyah,Hamkamempunyaiperan dalam menyumbangkan isi pikirannya tentang kepribadian Muhammadiyah dan secara garis besar Hamka setuju dengan apa yang diucapkan oleh K.H. Fakih Usman. Hamka menambahkan bahwa kepribadian Muhammadiyah tidak akan muncul terlihat jika tidak ada kepribadian pemimpinnya (Hamka, 1962, hlm. 1). Hal itulah yang menjadi dasar Hamka menerima usulan kepribadian Muhammadiyah yang diusulkan atas prakarsa K.H. Fakih Usman.

\section{SIMPULAN}

Jika dilihat dari silsilah keturunannya, Hamka berasal dari keluarga yang taat beragama serta mempunyai status sosial yang cukup tinggi di lingkungannya. Hal tersebut yang membuat ayahnya yakni Haji Abdul Karim Amrullah atau lebih dikenal sebagai Haji Rasul mendidiknya dengan keras agar kelak Hamka menjadi penerusnya dimasa yang akan datang. Pendidikan yang ditempuh oleh Hamka hanya sampai kelas dua di Sekolah Desa sehingga hingga akhir hayatnya Hamka tidak memiliki ijazah diplomat resmi. Tahun 1925, Buya Hamka pertama kalinya bergabung dengan Muhammadiyah. SelamabergabungdenganMuhammadiyah, banyak apa yang telah dilakukan oleh Buya Hamka sehingga beberapa kali ditunjuk sebagai pimpinan cabang Muhammadiyah hingga menjadi penasihat pimpinan pusat Muhammadiyah.

Buya Hamka membawa Muhammadiyah ke luar Jawa dibantu oleh saduara beserta ayahnya meskipun sampai akhir hayatnya Haji Rosul tidak terdaftar sebagai anggota Muhammadiyah. Kemudian upaya yang dilakukan oleh Buya Hamka dalam mengembangkan Muhammadiyah diantaranya adalah membangun Kulliyatul Muballighin. Perguruan ini awalnya bernama Tabligh School hingga akhirnya setelah melalui beberapa perbaikan maka namanya berubah menjadi Kulliyatul Muballighin. Perguruan yang secara resmi berdiri tahun 
1935 ini kelak akan melahirkan banyak tokoh-tokoh agama yang berpengaruh di Indonesia.

Lalu merumuskan status Muhammadiyah didalam Masyumi. Buya Hamka kembali dilibatkan dalam sebuah tim yang bertujuan untuk menyelesaikan persoalan mengenai status Istimewa Muhammadiyah dalam Masyumi karena dikhawatirkan akan mengganggu keharmonisan hubungan Muhammadiyah dengan Masyumi. Meskipun tidak mudah, namun pada akhirnya tim tersebut dapat menyelesaikan persoalan sehingga tidak menimbulkan perpecahan antara Muhammadiyah dengan Masyumi. Kemudian Buya Hamka ikut dalam merumuskan Muqaddimah Anggaran Dasar Muhammadiyah. Rumusan tersebut dapat diselesaikan oleh Buya Hamka beserta teman-temannya dengan baik, saat itu Muhammadiyah dipimpin oleh Ki Bagus Hadikusumo dan Buya Hamka membantu dalam penyusunan Kepribadian Muhammadiyah yang dijadikan pegangan bagi anggota Muhammadiyah yang ingin terjun ke dunia politik hingga saat ini.

\section{DAFTAR PUSTAKA}

Aizid, R. (2017). Para Pelopor Kebangkitan Islam. Yogyakarta: DIVA Press.

Alfian, M.A. (2014). HAMKA dan Bahagia. Bekasi: PT. Penjuru Ilmu Sejati.

Arifin,M.T.(1987).GagasanPembaharuan Muhammadiyah. Jakarta: Pustaka Jaya.

Djamal, M. (2002). DR. H. Abdul Karim Amrullah: Pengaruhnya dalam Gerakan Pembaruan Islam di Minangkabau pada Awal Abad Ke-2O. Jakarta: INIS.

El-Jaquene, F.T. (2018). Buya Hamka. Yogyakarta: Araska.
Faidi, A. (2014). Jejak-Jejak Pengasingan Para Tokoh Bangsa. Yogyakarta: Saufa.

Gottschalk, L.(1986). Mengerti Sejarah. Jakarta: UI Press.

Hamka. (1962). Kepribadian Muhammadiyah Prasaran Hamka. Yogyakarta: PP Muhammadiyah.

Hamka, R.H. (2016). Pribadi dan Martabat Buya Prof. Dr. HAMKA. Tanpa Kota: Pustaka Panjimas.

Ismaun. (2005). Sejarah Sebagai Ilmu. Bandung: Historia Utama Press.

Kurniawan, S. \& Mahrus, E. (2011). Jejak Pemikiran Tokoh Pendidikan Islam. Jakarta: Ar-Ruzz Media.

Miswanto, A. (2012). Sejarah Islam dan Kemuhammadiyahan. Magelang: P3SI UMM.

Mujahid, A. (2013). Sejarah Muhammadiyah Bagian 1. Bandung: Toobagus Publishing.

Musyafa, H. (2016). HAMKA: Sebuah Novel Biografi. Bandung: Imania.

Noer, D. (1982). Gerakan Modern Islam di Indonesia 1900-1942. Jakarta: LP3ES.

Pasha, M. K. \& Darban, A.A. (2000). Muhammadiyah Sebagai Gerakan Islam. Yogyakarta: LPPI.

Ramly, N. \& Sucipto, H. (2010). Ensiklopedia Tokoh Muhammadiyah. Jakarta: Best Media Utama.

Rush, J. R. (2017). Adicerita HAMKA. Jakarta: PT. Gramedia Pustaka Umum. Sjamsuddin, H. (2007). Metodologi sejarah. Yogyakarta: Ombak.

Syaifullah. (1997). Gerak Politik Muhammadiyah Dalam Masyumi. Jakarta: Pustaka Utama Grafiti.

Historia. (2018). HAMKA: Ulama Serba Bisa dalam Sejarah Indonesia. Jakarta: Kompas. 